\title{
Tourism Impact on Marine Ecosystems in the North of Red Sea
}

\author{
Abderrahim Lakhouit ${ }^{1}$ \\ ${ }^{1}$ Department of Civil Engineering, Faculty of Engineering, University of Tabuk, Tabuk, Kingdom of Saudi \\ Arabia \\ Correspondence: Abderrahim Lakhouit, Department of Civil Engineering, Faculty of Engineering, University of \\ Tabuk, Tabuk, Kingdom of Saudi Arabia. E-mail: Abderrahim.lakhouit@Usherbrooke.ca
}

Received: November 18, 2019

doi:10.5539/jsd.v13n1p10
Accepted: December 10, 2019 Online Published: December 23, 2019

URL: https://doi.org/10.5539/jsd.v13n1p10

\begin{abstract}
The unique marine environment of the northern Red Sea region is among the richest and most productive marine ecosystems in the world. The sea is populated with extensive algae blooms and at least five types of coral reefs. However, the region's tourism sector is largely dependent on the surrounding environment, including the coral reefs, which are highly sensitive to human activities. A large tourist project (Neom) is scheduled to be installed in the northern Red Sea, further increasing tourist activities in the area and leading to human intrusion into crucial but fragile marine habitats such as seagrass beds, coral reefs and mangrove stands. The present study investigates how human activities are currently affecting Red Sea ecosystems. Field visits were done in order to investigate and to study human activities impact on marine ecosystems in the north of Red Sea. To the best of our knowledge, this work is the first of its kind to evaluate the impact of tourism on marine ecosystems in Saudi Arabia's northern Red Sea coast.
\end{abstract}

Keywords: Red Sea, Neom, marine ecosystems, tourism, marine pollution

\section{Introduction}

Although coastal areas along the Red Sea are sparsely populated, touristic and industrial activities around Aqaba (Fig. 1) have altered coastline morphology and created a plethora of erosion and sedimentation problems in the entire region (Barale, 2007). For example, tourist activities have inflicted damage on coral reefs through careless anchoring of boats and insensitive diving (Loya, 1975; Walker and Ormond, 1982; Riegl and Luke, 1999; Zakai and Chadwick-Furman, 2002; Abelson et al., 2005; Hasler and Ott, 2008), endangering reef ecosystems (Haas et al., 2010a). A major result of the introduction of tourism into the region is that coral communities may change in the near future and many coral species may disappear (Riegl et al., 2012a).

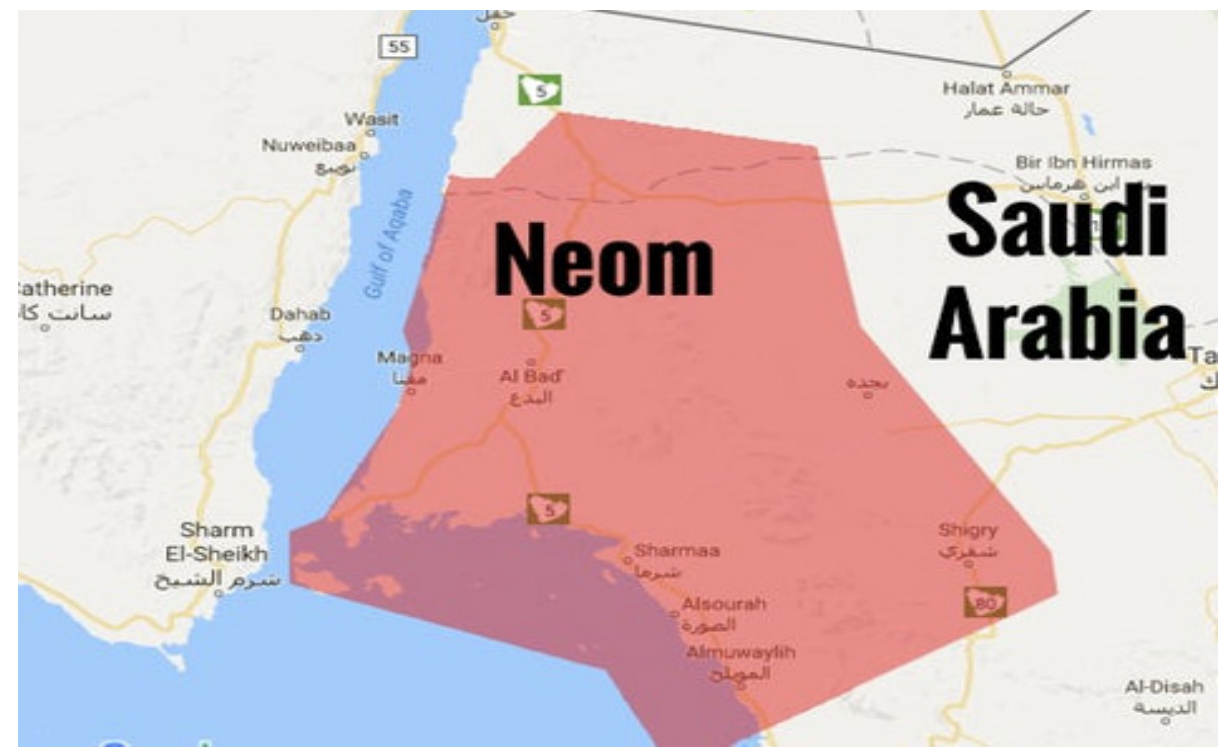

Figure 1. Neom location 
Because of their importance to the overall health of the Red Sea ecosystem, coral communities have been investigated in the northern Red Sea and in the gulfs of Suez and Aqaba. Results show that the coral reefs situated near urban activities (Riegl and Luke, 1999; Wielgus et al., 2004; Abelson et al., 2005; Hasler and Ott, 2008) have been heavily damaged due to population expansion, touristic activities, coastal development, and associated declines in water quality (Loya, 1975; Walker and Ormond, 1982; Riegl and Luke, 1999; Richter et al., 2001; Zakai and Chadwick-Furman, 2002; Wielgus et al., 2004; Abelson et al., 2005; Hasler and Ott, 2008; Haas et al., 2010a).

Previous researchers have broadly classified five types of coral frameworks in the region: Acropora reef framework, porites reef framework, porites carpet, faviid carpet, and stylophora carpet. Two non-framework community types were also found: the stylophora-acropora community and soft coral communities (Riegl and Luke, 1999; Riegl and Piller, 1999; Zuschin et al., 2000). According to Acker et al. (2008), complexes of large coral reefs could provide a source for chlorophyll-rich sediment or nutrients. In this way, chlorophyll concentrations are increased near reefs, making the Red Sea the preferred site for many species.

In the sea, coral reefs are mainly distributed along the northern and central coasts (Roberts and Ormond, 1987; Riegl and Luke, 1999; Riegl and Piller, 1999), with the Saudi coast being home to the most extensive areas of Red Sea coral reefs (Roberts and Ormond, 1987; Hawkins and Roberts, 1994; Barale, 2007). The reefs are particularly well developed in the north and central portions of the sea (Riegl and Luke, 1999; Riegl and Piller, 1999). Mangroves also thrive in the region and are represented by three species: Avicennia marina, Rhizophoramucronata, and Bruguieragymnorhiza (Mandura, 1997), while ten species of seagrass can also be found in the Red Sea (Vittorrio, 2007).

The present study looks at the current state of marine ecosystems in the Red Sea, focusing on the northern portion along the Saudi Arabian coast. To the best of our knowledge, this is the first study to evaluate the impact of tourism activities on marine ecosystems in this region. The work also looks at how the futuristic city of Neom, which will be built in the Gulf of Aqaba, will impact the Red Sea's ecosystems. As shown in Fig. 1, Neom is a planned 10,230-square-mile transnational city and economic zone that is scheduled for construction in the border region of Saudi Arabia, Jordan, and Egypt. Some of the work on Neom has already been started.

\section{Materials and Methods}

The main objective of the present paper is to summarize the overall human activities impact on the north of Red Sea (Especially Neom Area). More details of study area (Neom city) was discussed and listed in the introduction of this paper. The study area was visited during many times to study and to investigate directly the impact of human activities (coastal construction, tourism activities, recreation, industries, and infrastructures) on marine ecosystems. An analysis of all the human impacts and pressures on marine ecosystems is examined by looking at the direct impact of the Neom project. In fact, Neom is a new city will be constructed to attract tourism in the world. In parallel of the field visit an extensive literature was done. The impact of human activities on Red Sea. Among these articles, few studies focused on the north Red Sea especially the Aqaba Gulf. A comparison was done between the north Red Sea of Egypt, coastal (the neighbor in the other side of Red Sea) and Saudi Arabia coastal. According the literature, the Egyptian government has encouraged marine tourism in the north of Red Sea from 1990. A huge marine impact has been observed. Therefore, the present paper investigates the human activity impacts on marine ecosystems.

\section{Results and Discussions}

\subsection{Tourism in the Red Sea}

To develop the tourism sector in the Saudi Arabian portion of the northern Red Sea, extensive infrastructure (e.g., ports, hotels, highways, airports, wastewater treatment plants, power generating sources, restaurants, parks, parking, scuba diving sites, etc.) needs to be installed and constructed. However, much of this infrastructure is a source of pollution from the time of its construction and throughout the time of its use. For example, tourist activities such as swimming, fireworks, surfing, sailboarding, dinghy sailing and scuba diving are all major sources of pollution. Motorboats pollute the air, water and soil, while the chemical paint on boats pollutes the water. These pollution-causing activities and infrastructure negatively affect the Red Sea's marine ecosystems.

In general, coral reefs provide a major impetus for tourist development (Hawkins and Roberts, 1994). The Red Sea possesses many different types of marine and coastal areas which encourage and enhance the tourist industry (Gladstone et al., 2013). Unfortunately, significant local impacts have occurred due to rapid human population growth and urbanization, coastal construction, tourism, reef over-usage and destructive fisheries. Along urbanised coastlines, urban infrastructure is increasingly becoming the dominant habitat, with the coastal zone 
suffering increasing collateral damage from continuing urban development and construction. Moreover, the coral reefs in and around the northern Red Sea have become famous world-wide as a favorite recreational diving site, with diving becoming a booming branch of the tourism business (Musa and Dimmock, 2012). The aforementioned project Neom (Fig. 1), which will be installed in northern Saudi Arabia, will be contributing to the transformation of the coastal landscape that results from the increasing demand for urban infrastructure to sustain tourist activities.

\subsection{Pollution in the Red Sea}

Marine pollution can be defined as the direct or indirect introduction of substances into a marine environment that is harmful to marine and human health. Such pollution also causes a hindrance to marine activities, including fishing and other legitimate uses of the sea, impairment of quality of sea water, and reduction in amenities. The Red Sea coastal areas are largely affected by marine pollution, including oil spills, urban discharges, and industrial wastewater (Abohassan, 2013). This type of pollution represents one of the main factors for the overall environmental pollution problem that has grown as a direct result of human activities. In the present paper, marine pollution refers to all human activities that cause damage to or decay of sea water characteristics and that lead to defects in the environmental system by decreasing its capability of fulfilling its natural role.

One of the biggest tourism-related human activities threatening coral reef ecosystems is intensive recreational scuba diving. Zones that experience heavy scuba diving activity also showed greater damage to corals and a decrease in coral cover compared to reefs that were less popular for diving (Hasler and Ott, 2008). In another study (Riegl and Velimirov, 1991), a comparison was made between reefs that had few visitors and those that had numerous visitors. Although coral breakage was found in both categories, there were significantly higher levels of damage in those reefs that received the most visitors.

In tandem with tourism growth, industrial activities in the coastal area of Saudi Arabia have increased dramatically and resulted in the continuous invasion of different types of pollutants, including heavy metals (Badr et al., 2009). According to Badr et al. (2009), elevated concentrations of lead were recorded in the bottom layers of cores in Jeddah. Three coral species, Porites lutea, Goniastrearetiformis and Pocilloporaverrucosa, were analysed for $\mathrm{Hg}, \mathrm{Cu}, \mathrm{Zn}, \mathrm{Pb}, \mathrm{Mn}, \mathrm{Fe}, \mathrm{Ni}, \mathrm{Cd}, \mathrm{V}, \mathrm{Al}, \mathrm{Cr}, \mathrm{Mg}, \mathrm{B}, \mathrm{Ca}$, and $\mathrm{Sr}$ in both skeletal and soft tissues. The results show that corals in the polluted areas have significantly higher concentrations of trace elements compared to corals in unpolluted areas (Hanna and Muir, 1990). Overall, the main marine and coastal environmental threats are uncontrolled tourism expansion, navigation risks, transport of petroleum products, destruction of habitats, and using marine resources in a non-sustainable way.

\subsection{Ecosystem of the Red Sea}

Marine habitats include coral reefs, mangroves, seagrass beds, as well as extensive areas of fringing reef dominated by a diverse coral community or a mixture of coral and macro algae (Gladstone, 2000). The following sections provide details on these ecosystems.

\subsubsection{Coral Reefs}

Throughout the Red Sea ecosystem, there is not only significant biological diversity but a high percentage of endemism, meaning species that are unique to the area. Several locations and species have global conservation merit, such as the Socotra Archipelago and the coral reef in the northern and central parts of the Red Sea (Fig. 2). According to numerous authors, the Red Sea coral reef ecosystem is characterized by high endemism (Roberts and Ormond, 1987; Hawkins and Roberts, 1994; Riegl and Luke, 1999; Riegl and Piller, 1999). For example, of the 1200 coral reef fish species recorded, about $10 \%$ are endemic to the Red Sea (Roberts and Ormond, 1987; Hawkins and Roberts, 1994; Zakai and Chadwick-Furman, 2002). Furthermore, while representing only $0.2 \%$ of the world's oceans, the Red Sea supports around $6 \%$ of the world's coral reefs. 


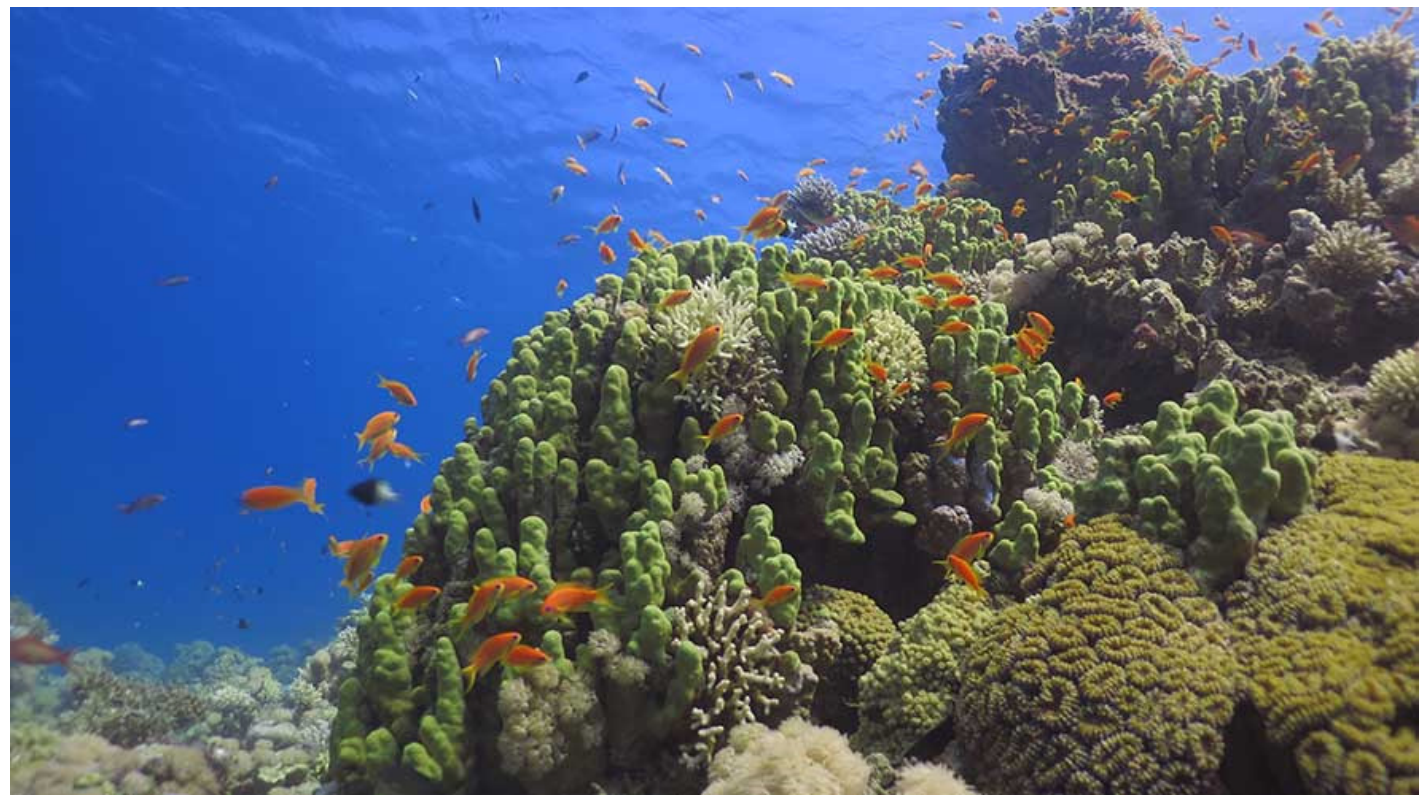

Figure 2. Coral reef

The principle reef types are fringing reefs along the mainland coast. These often extend across or into coastal bays (sharma) and around islands. The patch and platform reefs and the barrier reefs are situated further offshore(DeVantier et al., 2000). According to DeVantier et al. (2010), there are 116 coral species in the Red Sea.

Climate change is a major threat to the future of the world's coral reefs, and reports from the Red Sea suggest that coral growth has slowed (Riegl et al., 2012b). The most immediate threats to coral reefs differ in the region but are rising with the increasing rate of coastal development. The main threats to the local Red Sea environment near cities and current/proposed tourist zones are sewage discharge (desalination infrastructure), sedimentation, dredging and landfills, as well as ongoing reef damage due to boat anchors. A portion of the decline in coral reefs is attributed to physical damage caused by divers. Coral reefs worldwide are attracting increasing numbers of scuba divers, leading to growing concerns about damage (Barker and Roberts, 2004).

\subsubsection{Mangroves}

Mangrove ecosystems exist in tropical and subtropical seas. They are found on flat land between high and low water marks. Mangrove plants constitute a group of about 80 halophytic species that have adapted to survival in saline water (Mandura, 1997). They have an enormous value as habitats, food sources, and refuges for marine organisms (Mandura, 1997). Red Sea mangroves do not grow as luxuriously as most other tropical mangroves due to conditions of high salinity, poor soil textures, low precipitation and low nutrient concentrations. Their growth in the southern part of the Red Sea is relatively denser and more luxurious than in the north (Mandura, 1997). They are represented by three species:Avicennia marina, Rhizophoramucronata, and Bruguieragymnorhiza(Mandura, 1997). Avicennia marina is the dominant species in the Red Sea (Mandura, 1997).

Mangrove systems occupy the intertidal areas of the coasts and thus are extremely exposed to heavy metal pollutants from various sources (Abohassan, 2013). In a recent study, mangrove sediments were found to be the main stocks for heavy metals, followed by mangrove wood, while only a minimal amount $(<3.5 \%)$ of heavy metals was returned back to the sediment via litterfall; of this amount, less than $1 \%$ was removed from the mangrove system via tidal activities (Abohassan, 2013). Human activities have a direct and deleterious effect on Red Sea mangroves. For example, avicennia marina mangroves in the northern Red Sea are heavily oiled.(Dicks, 1986). The northern Red Sea coastal regions of Saudi Arabia are witnessing rapid changes in urbanization and tourism activities, altering traditional land use and adversely impacting the mangrove cover in the region through pollution (Kumar et al., 2010).

\subsubsection{Seagrass}

Seagrasses, which are marine flowering plants, are widely distributed along the world's temperate and tropical coastlines. Seagrasses contribute immensely to coastal ecosystems and can form extensive meadows supporting 
high biodiversity(Short et al., 2007). According to Barale Vittorrio (2007), ten species of seagrass are widespread in the Red Sea. The Red Sea is an intense blue-green in color; occasionally, however, it is populated by extensive blooms of the algae Trichodesmium Erythraeum (Carpenter and Capone, 1992; Krishnan et al., 2007; Haas et al., 2010b; Padmakumar et al., 2010), which, upon dying off, turns the sea a reddish brown colour, hence giving the Red Sea its name. An algae bloom is shown in Fig. 3. Macroalgaesuch as Caulerpaserrulata, Peyssonneliacapensis and filamentous turf algae are also found in the region (Haas et al., 2010a).

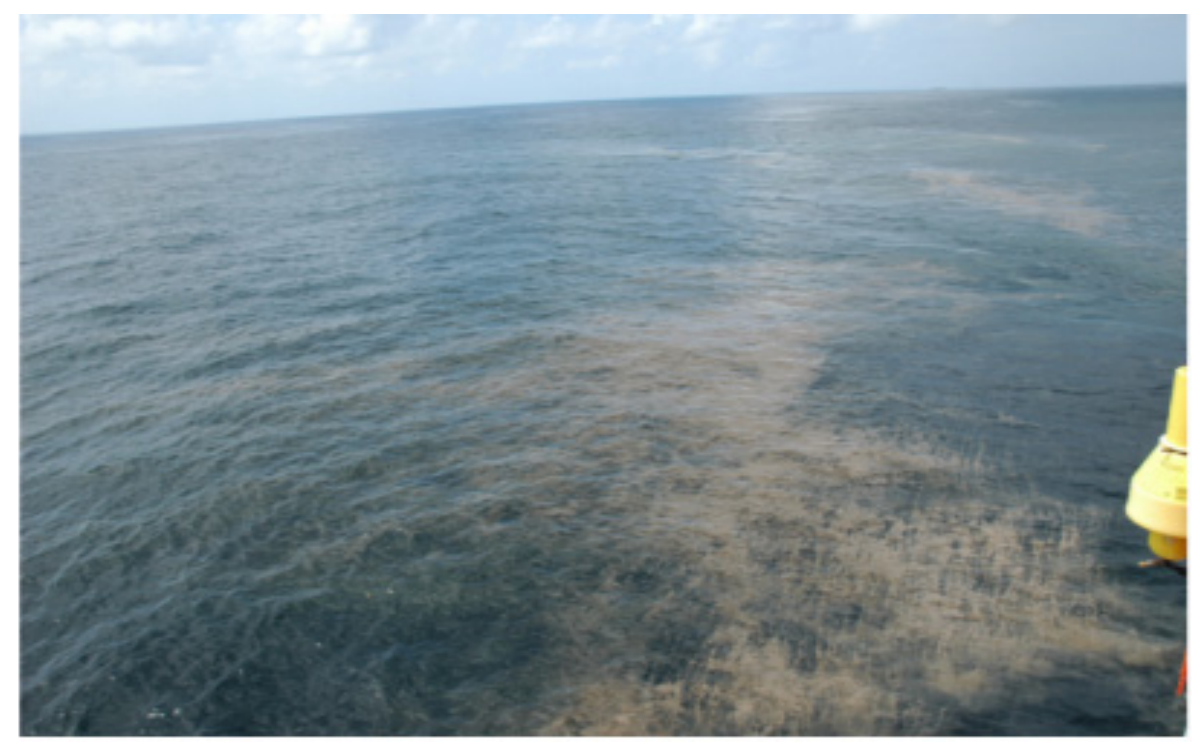

Figure 3. Algae Trichodesmium bloom

Source: (Padmakumar et al., 2010)

There are more than 70 species of seagrasses. Those found in the Red Sea are listed in Table 1. In the Aqaba Gulf, only eight species (Fig. 4) were found (El Shaffai, 2011). These species are grouped into two families: Cymodoceaceae and Hydrocharitaceae.

Table 1. Family cymodoceaceae family hydrocharitaceae

\begin{tabular}{ll}
\hline Family Cymodoceaceae & Family Hydrocharitaceae \\
\hline Cymodocea rotundata & Enhalus acoroides \\
Cymodocea serrulata & Halophila decipiens \\
Halodule pinifolia & Halophila ovalis \\
Halodule uninervis & Halophila ovata \\
Syringodium isoetifolium & Halophila stipulacea \\
Thalassodendron ciliatum & Thalassia hemprichii \\
\hline
\end{tabular}

Source: (Price et al., 2009; El Shaffai, 2011; Serrano et al., 2018) 


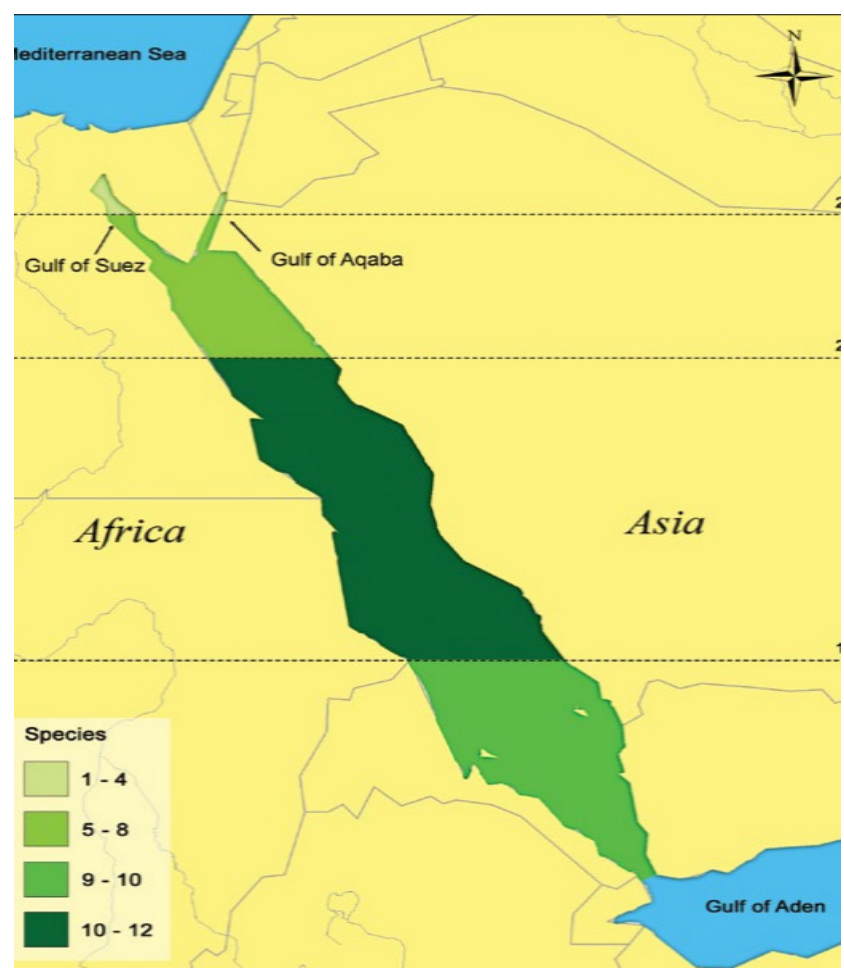

Figure 4. Distribution of seagrasses in the Red Sea

Source: (El Shaffai, 2011)

In general, seagrasses contribute to climate change mitigation by serving as carbon dioxide sinks; they also help protect the shoreline from rising sea levels (Serrano et al., 2018). Seagrasses have been found to sequester approximately $0.8 \%$ of carbon dioxide emissions caused by fossil-fuels (Serrano et al., 2018). According to El Shafai (2011), seagrass diversity is uneven in the Red Sea. Seven species are known in the Gulf of Aqaba and five in the Gulf of Suez. El Shafai (2011) noted that all species in the Red Sea originated from the Indian Ocean, and that at least one species, Halophilastipulacea, had entered the Mediterranean Sea via the Suez Canal. Seagrasses are one of the most valuable marine ecosystems on earth and can form extensive meadows supporting high biodiversity. The main ecological functions of seagrasses are:

- Providing an important habitat for a number of organisms.

- Providing nursery areas.

- Sheltering animals that serve as food to other marine animals, such as manatees and sea turtles.

- Stabilizing the ocean bottom through root systems.

- Helping to "clear" water by trapping sediments and small particles in the water column.

- Boosting local economies through supporting vibrant recreation opportunities.

The current extreme conditions caused in large part by human activities in the Red Sea are leading to nutrient limitation, which is turn is reducing seagrass growth rates (Serrano et al., 2018).

\section{Conclusions}

The northern Red Sea coastal region is characterized by its sensitive, fragile, unique natural resources and habitats. The present study investigated the impacts of human activities on this ecosystem. Investigations such as this one are very important for future proper planning of coastal areas. Moreover, documentation of the impacts that human activities are having on the region can help decision-makers by increasing public awareness about negative effects caused by unsustainable practices. The coastline of the northern Red Sea has experienced considerable environmental stress over the past few decades from tourist and residential recreational activities. As discussed in this paper, tourist-relatedactivities - especially diving - have already caused substantial damage to inshore coral reefs, mangroves and seagrasses, and the recent literature has shown that marine ecosystems have been heavily damaged due to population expansions, touristic activities and coastal development. 
Another area of concern discussed in this work is the tourist development project "Neom", which will be installed in the Aqaba Gulf. Neom will involve the construction of numerous hotels, bridges, residential and commercial buildings, an airport, seaports, and other infrastructure. Some of these buildings and infrastructure have already been built or are under construction, in line with Saudi Arabia's "vision 2030" manifesto for the region. However, these human activities have caused extensive marine pollution, which hasthe potential to seriously damage Red Sea ecosystems by placing extra stress on organisms that are already threatened or endangered. To conserve the endemic species of coral reefs, algae, and fish in the northern Red Sea, many efforts need to be made, starting with more qualitative and quantitative studies focusing on this region.

\section{References}

Abelson, A., Olinky, R., \& Gaines, S. (2005). Coral recruitment to the reefs of Eilat, Red Sea: temporal and spatial variation, and possible effects of anthropogenic disturbances. Marine Pollution Bulletin, 50, 576-582. https://doi.org/10.1016/j.marpolbul.2005.02.021

Abohassan, R. A. (2013). Heavy Metal Pollution in Avicennia marina Mangrove Systems on the Red Sea Coast of Saudi Arabia. Journal of King Abdulaziz University: Meteorology, Environment \& Arid Land Agriculture Sciences, 24. https://doi.org/10.4197/Met.24-1.3

Badr, N. B., El-Fiky, A. A., Mostafa, A. R., \& Al-Mur, B. A. (2009). Metal pollution records in core sediments of some Red Sea coastal areas, Kingdom of Saudi Arabia. Environmental Monitoring and Assessment, 155, 509-526. https://doi.org/10.1007/s10661-008-0452-x

Barale, V. (2007). Marine and coastal features of the Red Sea. European Commission, EUR 23091, 56.

Barker, N. H., \& Roberts, C. M. (2004). Scuba diver behaviour and the management of diving impacts on coral reefs. Biological Conservation, 120, 481-489. https://doi.org/10.1016/j.biocon.2004.03.021

Carpenter, E. J., \& Capone, D. G. (1992). Nitrogen fixation in Trichodesmium blooms. Marine pelagic cyanobacteria: Trichodesmium and other diazotrophs. Springer, pp. 211-217. https://doi.org/10.1007/978-94-015-7977-3_13

DeVantier, L., Turak, E., Al-Shaikh, K., \& De ath, G. (2000). Coral communities of the central-northern Saudi Arabian Red Sea. Fauna of Arabia, 18, 23-66.

Dicks, B. (1986). Oil and the black mangrove, Avicennia marina in the northern Red Sea. Marine Pollution Bulletin, 17, 500-503. https://doi.org/10.1016/0025-326X(86)90638-7

El Shaffai, A. (2011). Field guide to seagrasses of the Red Sea. by: IUCN, Gland, Switzerland and Total Foundation, Courbevoie, France.

Gladstone, W. (2000). The ecological and social basis for management of a Red Sea marine-protected area. Ocean \& Coastal Management, 43, 1015-1032. https://doi.org/10.1016/S0964-5691(00)00070-3

Gladstone, W., Curley, B., \& Shokri, M. R. (2013). Environmental impacts of tourism in the Gulf and the Red Sea. Marine Pollution Bulletin, 72, 375-388. https://doi.org/10.1016/j.marpolbul.2012.09.017

Haas, A., el-Zibdah, M., \& Wild, C. (2010). Seasonal monitoring of coral - algae interactions in fringing reefs of the Gulf of Aqaba, Northern Red Sea. Coral Reefs, 29, 93-103. https://doi.org/10.1007/s00338-009-0556-y

Haas, A. F., Naumann, M. S., Struck, U., Mayr, C., el-Zibdah, M., \& Wild, C. (2010). Organic matter release by coral reef associated benthic algae in the Northern Red Sea. Journal of Experimental Marine Biology and Ecology, 389, 53-60. https://doi.org/10.1016/j.jembe.2010.03.018

Hanna, R., \& Muir, G. (1990). Red Sea corals as biomonitors of trace metal pollution. Environmental Monitoring and Assessment, 14, 211-222. https://doi.org/10.1007/BF00677917

Hasler, H., \& Ott, J. A. (2008). Diving down the reefs? Intensive diving tourism threatens the reefs of the $\begin{array}{llllll}\text { northern } & \text { Red } & \text { Sea. Marine Pollution } & \text { Bulletin, }\end{array}$ https://doi.org/10.1016/j.marpolbul.2008.06.002

Hawkins, J. P., \& Roberts, C. M. (1994). The growth of coastal tourism in the Red Sea: present and future effects on coral reefs. Ambio, 23, 503-508.

Krishnan, A. A., Krishnakumar, P. K., \& Rajagopalan, M. (2007). Trichodesmium erythraeum (Ehrenberg) bloom along the southwest coast of India (Arabian Sea) and its impact on trace metal concentrations in seawater. Estuarine, Coastal and Shelf Science, 71, 641-646. https://doi.org/10.1016/j.ecss.2006.09.012

Kumar, A., Khan, M. A., \& Muqtadir, A. (2010). Distribution of mangroves along the Red Sea coast of the 
Arabian Peninsula: Part-I: the northern coast of western Saudi Arabia. Earth Science India 3.

Loya, Y. (1975). Possible effects of water pollution on the community structure of Red Sea corals. Marine Biology, 29, 177-185. https://doi.org/10.1007/BF00388987

Mandura, A. (1997). A mangrove stand under sewage pollution stress: Red Sea. Mangroves and Salt marshes, 1, 255-262. https://doi.org/10.1023/A:1009927605517

Musa, G., \& Dimmock, K. (2012). Scuba diving tourism: introduction to special issue. Tourism in Marine Environments, 8, 1. https://doi.org/10.3727/154427312X13262430523947

Padmakumar, K., Smitha, B., Thomas, L. C., Fanimol, C., SreeRenjima, G., Menon, N., \& Sanjeevan, V. (2010). Blooms of Trichodesmium erythraeum in the South Eastern Arabian Sea during the onset of 2009 summer monsoon. Ocean Science Journal, 45, 151-157. https://doi.org/10.1007/s12601-010-0013-4

Price, A. R. G., Crossland, C. J., Dawson Shepherd, A. R., McDowall, R. J., Medley, P. A. H., Stafford Smith, M. G., ... Wrathall, T. J. (2009). Aspects of Seagrass Ecology along the Eastern Coast of the Red Sea. Botanica Marina, p. 83.

Richter, C., Wunsch, M., Rasheed, M., Katter, I., \& Badran, M. I. (2001). Endoscopic exploration of Red Sea coral reefs reveals dense populations of cavity-dwelling sponges. Nature, 413, 726. https://doi.org/10.1038/35099547

Riegl, B., \& Luke, K. E. (1999). Ecological Parameters of Dynamited Reefs in the Northern Red Sea and their Relevance to Reef Rehabilitation. Marine Pollution Bulletin, 37, 488-498. https://doi.org/10.1016/S0025-326X(99)00104-6

Riegl, B., \& Piller, W. E. (1999). Coral frameworks revisited - reefs and coral carpets in the northern Red Sea. Coral Reefs, 18, 241-253. https://doi.org/10.1007/s003380050188

Riegl, B., \& Velimirov, B. (1991). How many damaged corals in Red Sea reef systems? A quantitative survey. Hydrobiologia. Springer, pp. 249-256. https://doi.org/10.1007/BF00026471

Riegl, B. M., Bruckner, A. W., Rowlands, G. P., Purkis, S. J., \& Renaud, P. (2012). Red Sea coral reef trajectories over 2 decades suggest increasing community homogenization and decline in coral size. PloS one 7, e38396-e38396. https://doi.org/10.1371/journal.pone.0038396

Roberts, C. M., \& Ormond, R. F. (1987). Habitat complexity and coral reef fish diversity and abundance on Red Sea fringing reefs. Marine Ecology Progress Series, 1-8. https://doi.org/10.3354/meps041001

Serrano, O., Almahasheer, H., Duarte, C. M., \& Irigoien, X. (2018). Carbon stocks and accumulation rates in Red Sea seagrass meadows. Scientific reports, 8, 15037. https://doi.org/10.1038/s41598-018-33182-8

Short, F., Carruthers, T., Dennison, W., \& Waycott, M. (2007). Global seagrass distribution and diversity: a bioregional model. Journal of Experimental Marine Biology and Ecology, 350, 3-20. https://doi.org/10.1016/j.jembe.2007.06.012

Walker, D. I., \& Ormond, R. F. G. (1982). Coral death from sewage and phosphate pollution at Aqaba, Red Sea. Marine Pollution Bulletin, 13, 21-25. https://doi.org/10.1016/0025-326X(82)90492-1

Wielgus, J., Chadwick-Furman, N. E., \& Dubinsky, Z. (2004). Coral cover and partial mortality on anthropogenically impacted coral reefs at Eilat, northern Red Sea. Marine Pollution Bulletin, 48, 248-253. https://doi.org/10.1016/j.marpolbul.2003.08.008

Zakai, D., \& Chadwick-Furman, N. E. (2002). Impacts of intensive recreational diving on reef corals at Eilat, northern Red Sea. Biological Conservation, 105, 179-187. https://doi.org/10.1016/S0006-3207(01)00181-1

Zuschin, M., Hohenegger, J., \& Steininger, F. F. (2000). A comparison of living and dead molluscs on coral reef associated hard substrata in the northern Red Sea - implications for the fossil record. Palaeogeography, Palaeoclimatology, Palaeoecology, 159, 167-190. https://doi.org/10.1016/S0006-3207(01)00181-1

\section{Copyrights}

Copyright for this article is retained by the author(s), with first publication rights granted to the journal.

This is an open-access article distributed under the terms and conditions of the Creative Commons Attribution license (http://creativecommons.org/licenses/by/4.0/). 